News and views

\title{
Dating the Romanesque Mural Paintings and the Ducal Rotunda of St. Catherine, in Znojmo: New Discoveries (2010)
}

\author{
Kateřina Dvořákováa ${ }^{*}$ \\ ${ }^{a}$ Private professional expert, Absolonova 73, 62400 Brno, Czech Republic
}

\section{ARTICLE INFO}

\section{Article history:}

Received: 6 December 2010

Accepted: 20 January 2011

\section{Key words:}

religious architecture

Romanesque architecture

Romanesque painting

pigments

dating

interpretation

assessment

\begin{abstract}
Proving the correct interpretation and date of the murals in the ducal rotunda of St. Catherine in relation to the completion of the construction of the building lies within an historical event. On Pentecost in 1134 , on the occasion of the baptism of the second son of the prince Sobeslaus I, a wedding was agreed between Conrad II of Znojmo, and Mary of Serbia, sister of the Hungarian Queen. The pact between Sobeslaus I. and Conrad II. of Znojmo, concerning the future ascension of Conrad II of Znojmo to the throne of the principality of Prague, was to have been reinforced through this marriage. Conrad II of Znojmo had also recently regained power in the territory, which belonged to him through family title.
\end{abstract}

\section{Introduction}

Since they were first described by Mořic Trapp in 1861 many experts have speculated on the date of the Romanesque murals and the ducal rotunda of the church of St. Catherine in Znojmo. In this article I would like to present new discoveries regarding this question.

\section{Methodology of field work}

\subsection{Investigation of the murals with ultraviolet and infrared light}

A majority of outstanding questions related to the original appearance of the Romanesque murals in 1134, including the identification of later overpainting (from the $19^{\text {th }}$ and $20^{\text {th }}$ century), was clarified through this investigation.

Taking the murals in the dome of the apse, as an example, we can see on Trapp's coloured drawing the condition of the murals in 1861 (Figure 1) - which is limited to singular

"Corresponding author. E-mail: k-dvorakova@volny.cz body outlines. Let's focus ourselves on what was discovered later by other experts, in relation to the first restorations of the paintings, and what can we actually see in the paintings today.

Thanks to the discovery of Melicher's drawings, which were prepared for the restorative work on the murals in the rotund between 1891-1893, we know what the final appearance was after restoration. Melicher's project is very well documented with a photo taken in 1895 , by S. Vlk, a photographer from Znojmo. The restoration activities of František Fišer that followed were limited to local patches and conservation of some parts of the dome of the apse.

On Figure 2 we can see the present condition of the murals.

Since Melicher's restoration in the apse was completed there have been many evaluations of the style, composition and iconography of the murals. Some art historians from the end of $20^{\text {th }}$ century, even after the iconographic determination of the Deesis composition by Antonin Friedl considered, for example, that the figure of St. John the Baptist was a figure of St. John the Evangelist. Let's focus our attention to the two figures on the side - the Virgin Mary and St. John the Baptist. Ultraviolet images and infrared photographs show 

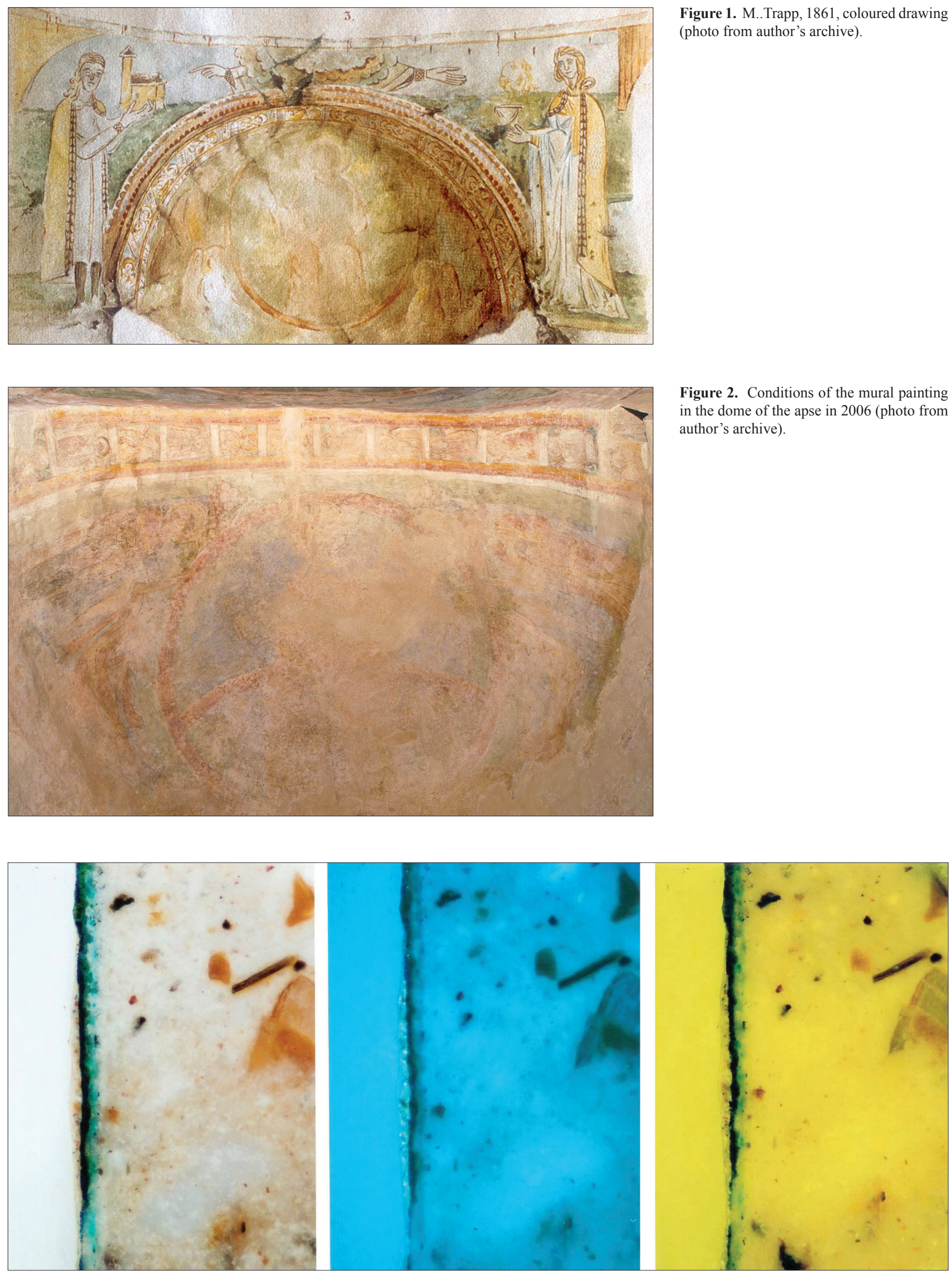

Figure 3. Stratigraphy of the paint layers (photo from author's archive).

Figure 2. Conditions of the mural painting in the dome of the apse in 2006 (photo from author's archive).

Figure 1. M..Trapp, 1861, coloured drawing (photo from author's archive). 
Figure 4. Dome of the apse, ultraviolet image of the mural in 2006 (photo from the author's archive).
Figure 5. Dome of the apse, infrared image of the mural in 2006 (photo from author's archive).
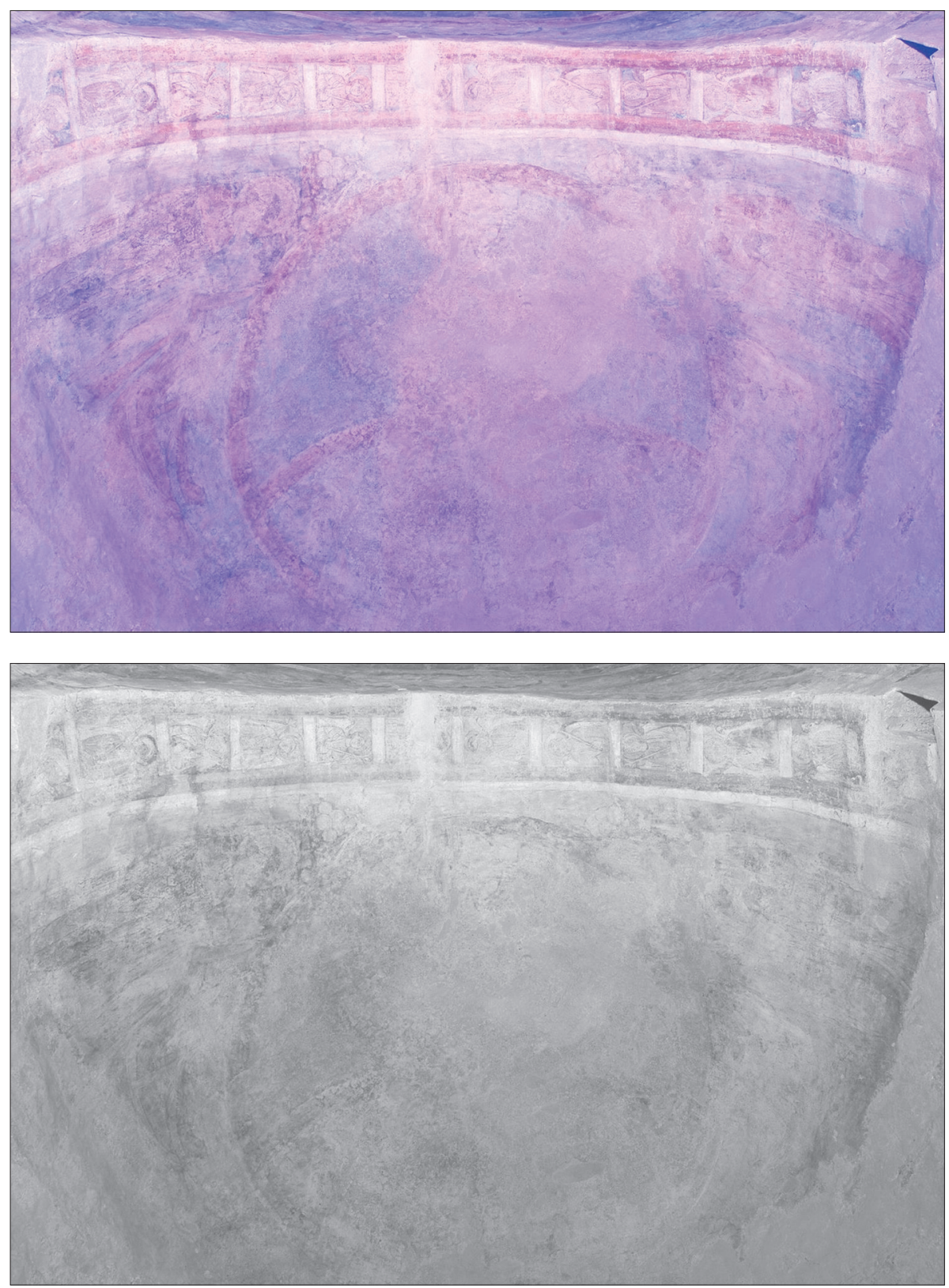

us a continuous painting on plaster, which could, except for the outlines, have been done as a secondary painting, because nothing more is conserved then this painting. It is obvious that without the identification of colour layers of the mural it would not be possible to verify opinions about the credibility of the restorations (Figure 3 ).

After comparing cross sections of samples, images from non-destructive ultraviolet and infrared investigation (Figure 4), and historical documents, it is possible to state that the best documentation of the mural's appearance is Trapp's aquarelle. The postures and shapes of figures correspond to the original appearance and to the discovered Deesis composition. Both lateral figures of Virgin Mary and St. John the Baptist were created by Melicher (as we know he used zinc white during the restoration - documented by the analysis of samples taken from select parts of the painting).
The hands of the Virgin Mary are not in their original state, in contrast to Konečný's comments, as shown on the coloured images of the Institute of Classical Studies of the Academy of Sciences of the Czech Republic. In this case there are parts of dropped plaster, salt efflorescence and mold that give the impression of a mural painting (Konečný 2005; Figure 6).

\subsection{Originally pigments of the Romanesque paintings}

As I discovered, the original Romanesque plaster is the same in every part of the painting, differing only in thickness. The thickness is as much as $8 \mathrm{~mm}$, while in some places the wall are exposed. An upper layer of glazed plaster onto which paint was applied (the "intonaco") is 2-4 mm thick. The original painting was done with lime and casein, with a lime and milk binding agent, on dry plaster with an "al secco" 


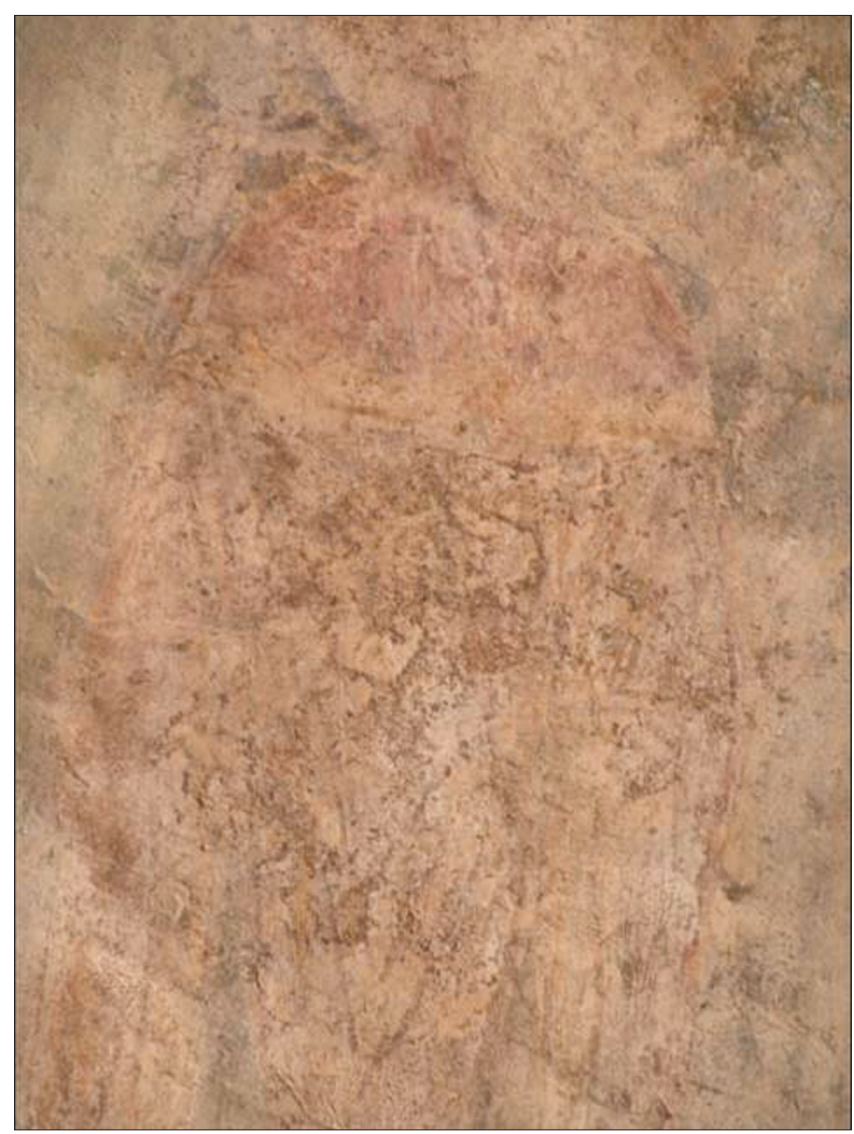

Figure 6. Hands of the Virgin Mary. Detail of parts of the mural which have fallen out, salt efflorescence and mold (photo from author's archive).

technique. The painting's composition was drawn with a brush. The third tier of the painting, the preliminary painting, was done in yellow. The painting itself was then done with red as the final colour. In other sections of the painting red is used for both preliminary and final painting. The tinted spaces were laid with a colour dissolved in limewater and milk. The following original elements were identified from pigment samples: green earth, yellow and brown ochres and lead white. The original blue pigment was most likely a blue ochre (vivianit) that is now identified on mural paintings from the $12^{\text {th }}$ century onwards. No overpaintings or chronological separation of parts of the mural were found in any investigations (restoration efforts, tests under ultraviolet or infrared light, sampling, nor from laboratory examinations conducted after the Second World War).

\subsection{Orientation of the building}

The ducal rotunda is orientated to the sunrise on the date of Assumption of Mary on $15^{\text {th }}$ August (adjusted to the Julian calendar). (Dvořáková, Hotárek 2008)

\subsection{Construction and scale of figures}

That the construction of the building and painting of the murals occurred in the same period (the $12^{\text {th }}$ century) are also shown by the recent discovery that the same scale was used in both the construction of the building and the Romanesque paintings

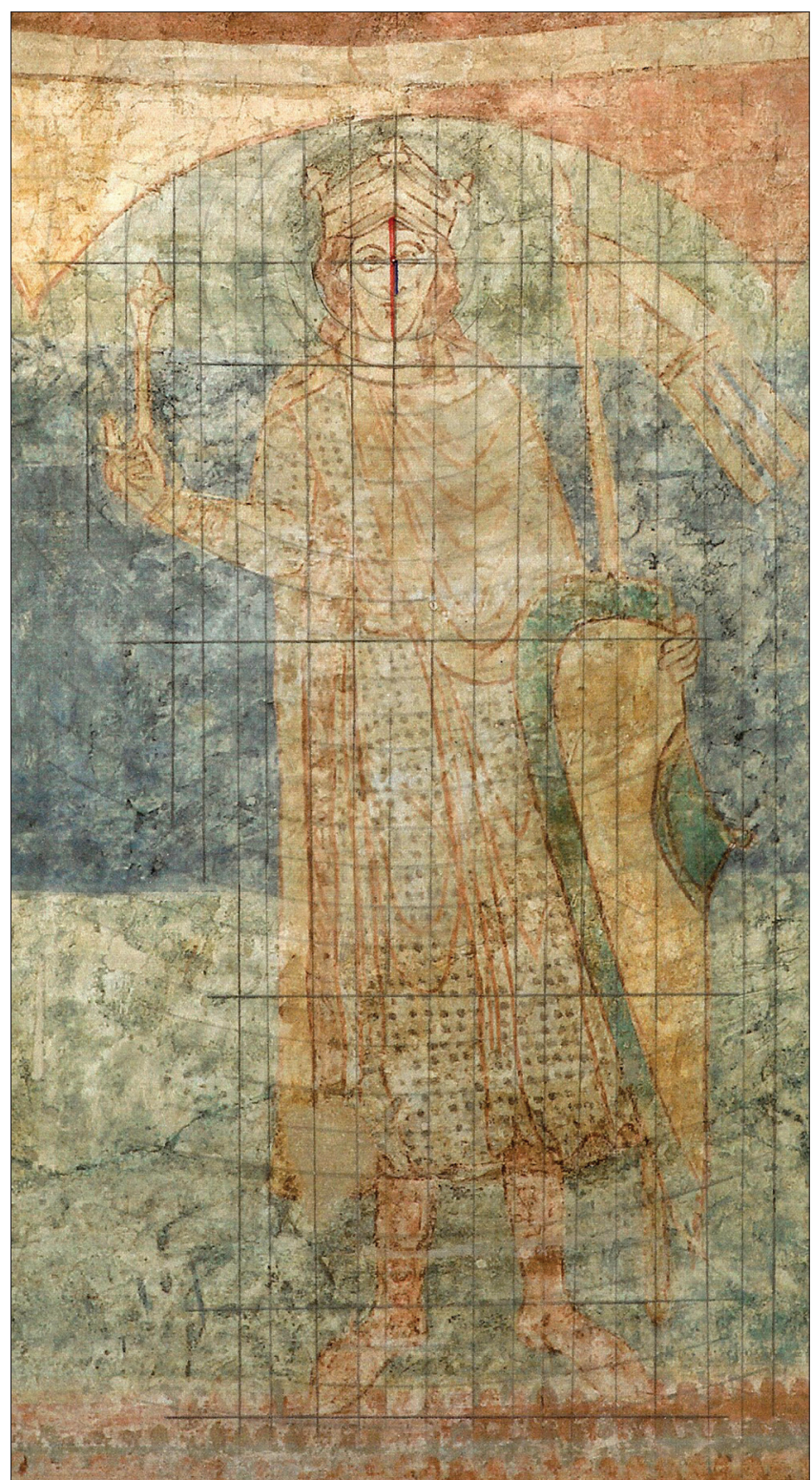

Figure 7. Rotunda of St. Catherine in Znojmo, figure of King Vratislaus II. Plan metric construction of the figure.

inside the ducal rotunda of Saint Catherine. The rotunda has an internal ground plan length of 33 feet (the age of Jesus Christ). Painters composed the figures in the same way, dividing the figures to 33 parts. The length of the nose served as basic size, a fact that had already been defined by the byzantine tradition and painting manual from Mount Athos (Painting manual from Mount Athos, Schäfer 1855). All images of rulers are created by the same construction principle (Figure 7).

\subsection{The collocation of King's figure}

The only figure of a King painted by the Romanesque painters, is not painted in the position of honour - opposite the altar as reported in art history literature - instead the figure is painted where the sun shines at sunrise at the summer solstice. After recalculation the date back to the Julian calendar, the date was found to exactly correspond to the date of the coronation 
Figure 8. Detail of seven holes in the cap of the dome of the rotunda. These holes, together with the painting of dove, symbolize the Descent of Holy Spirit on Pentecost, Whitsunday, 2006 (photo from author's archive).

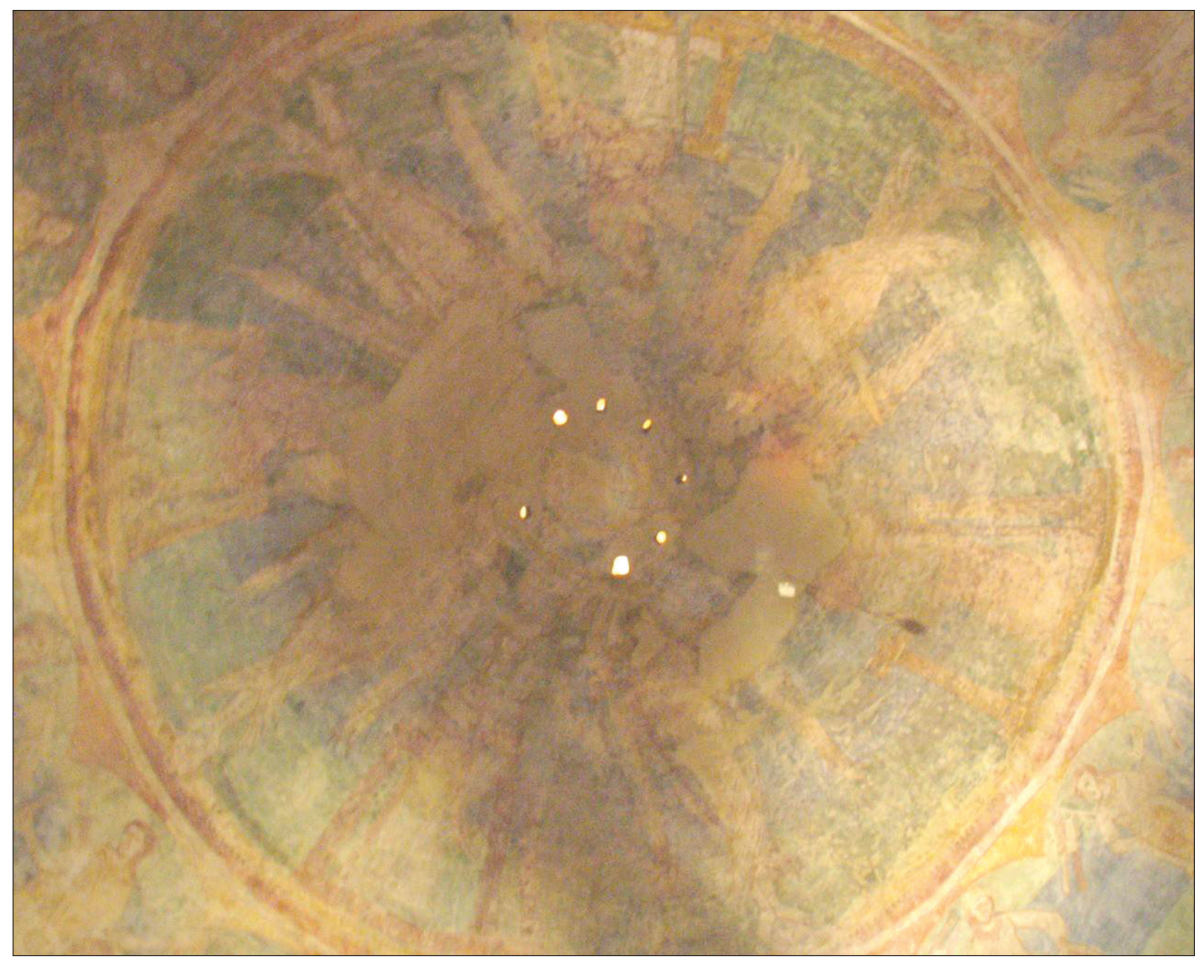

of Vratislaus I to both the Bohemian and Polish thrones - but only if the building had been constructed before 1134 .

\subsection{The spiritual function of the building}

Apart from other iconographic and iconological specifications which will be published later, there is another important discovery that proves the date of both building and painting. The central motive of the apse is Christ on the throne, in the position of Majestas Domini, where he is seen as the Ruler and Judge of all. The decoration of the ship culminates with the depiction of the descent of Holy Spirit in the dome, and by seven holes in the cap of the dome which were constructed for Pentecost (Figure 8).

The whole project of the construction of the rotund and creation of Romanesque paintings is mentally constricted to the Christian religion under the conduct and influence of the Holy Spirit, symbolized by a dove. It is obvious that the composition of the murals and the building's construction was intended and connected with the historical events for which it was constructed.

\section{Discussion of practical results}

\subsection{Results of the study of historical finds}

The proof of the correct interpretation and dating of the paintings, in relation to the completion of the construction of the building, lies within an historical event: on Pentecost 1134 , on the occasion of the baptism of the second son of the prince Sobeslaus I, a wedding was agreed between Conrad II of Znojmo, and Mary of Serbia, sister of the Hungarian Queen. The pact between Sobeslaus I. and Conrad II. of
Znojmo, concerning the future ascension of Conrad II of Znojmo to the throne of the principality of Prague, would have been reinforced through this marriage. Conrad II of Znojmo had also recently regained power in the territory, which belonged to him in accordance with family title.

"Interea dux Sobieslauslevirum suum, regem Ungarorum, rogabat, quatenus sororem coniugis, suae, videlicet reginae, principi Conrado Znoymensi in coniugium traderet, quo percusum foedus invicem huiusmodi causis corroboratum firmius perduraret." (Canon of Vyšehrad, 1134)

In the ducal rotunda we also find an inscription from 1134 that reads "CONRADUS SECUNDUS FUNDATOR".

The decisive confirmation of the date of the building and painting is the fact that the meaning of word "secundus" could, in accordance with middle age etymology, also mean "successor" (compare with similar uses of this word in FRB III, 336, or manuscript n. 9045 in Nationalbibliothek Wien - "Secundis sedentibus in thronis meis binis" - "To the successors, whom will be sitting on my dual throne").

The correct interpretation of this inscription does not consist in translation, that has been used in the professional literature up to date: "Conrad the second founder", but in middle age meaning, that clearly did mean "Conrad succesor fundator" of the ducal rotunda and their interior paintings and decorations.

\section{References}

\section{Written Sources}

COSMAE PRAGENSIS CHRONICA BOEMORUM. Bretholz, B. (Ed.), Berlin 1923. 
Archív Národního památkového ústavu, Brno Letter of Theofil Melicher $29^{\text {th }}$ october 1891 to the Comision Monument conservation department in Vienna.

LETOPISY HRADIŠŤSKO-OPATOVICKÉ, FONTES RERUM BOHEMICARUM T.II. Emler, J. (Ed.), Praha 1874.

KANOVNÍK VYŠEHRADSKÝ, FONTES RERUM BOHEMICARUM T.II. Emler, J.(Ed.), Praha 1874

MNICH SÁZAVSKÝ, FONTES RERUM BOHEMICARUM T.II. Emler, J.(Ed.), Praha 1874.

FONTES RERUM BOHEMICARUM T.III. Palacký, F. (Ed.), Praha 1884. CODEX DIPLOMATICUS ET EPISTOLARIS REGNI BOHEMIAE I Friedrich, G. (Ed.), Praha 1904-1907.

DAS HANDBUCH DER MALEREI VOM BERGE ATHOS. Schäfer, G. (Ed.), Trier 1855.

\section{Literature}

BINDIG, G., LINSCHEID-BURDICH, S. 2002: Planen und Bauen im frühen und hohen Mittelalter nach den Schriftquellen bis 1250. Wissenschaftliche Buchgesellschaft, Darmstadt.

DVOŘÁK, J. 1997: Horninový stavební materiál rotundy sv. Kateřiny na znojemském hradě. In: Ciprian, P.(Ed.): Znojemská rotunda ve světle védeckého poznání, védecká konference, 23.-25. 9. 1996. Jihomoravské muzeum ve Znojmě, Znojmo,138-140.

DVOŘÁKOVÁ, K. 2008: Identifikace pigmentů v rotundě sv. Kateřiny ve Znojmě. Ve službách archeologie 1/08, 81-84.

DVOŘÁKOVÁ, K., HOTÁREK, M. 2008: Orientace rotundy sv. Kateřiny ve Znojmě podle skutečného východu Slunce. Ve službách archeologie 2/08, 48-54.

FRIEDL, A. 1966: Přemyslovci ve Znojmě. Odeon, Praha.

HAŠEK, V., UNGER, J. 2010: Nedestruktivni metody průzkumu románských sakrálnich staveb na Moravě. Religious Architecture in the Czech Republic in the Light of Geophysical Prospection and Archeological Excavation, BAR International Series 2128, Oxford.

HÖSCHL, V., PUFFR, M., BÍLÝ, M. 1997: Geofyzikální průzkum románské rotundy sv. Kateřiny ve Znojmě. In: Ciprian, P. (Ed.): Znojemská rotunda ve světle vědeckého poznání, vědecká konference, 23.-25. 91996. Jihomoravské muzeum ve Znojmě, Znojmo, 149-160.

JAN, L. 1997: Několik poznámek k nejstarší církevní organizaci na Znojemsku. Časopis matice moravské 116, 39-51.

JAN, L. 1997: Několik poznámek k nejstarší církevní organizaci na Znojemsku. In: Ciprian, P. (Ed.): Znojemská rotunda ve světle vědeckého poznání, vědecká konference, 23.-25. 9. 1996. Jihomoravské muzeum ve Znojmě, Znojmo, 46-50.

KLÍMA, B. 1995: Znojemská rotunda ve světle archeologických výzkumů. Masarykova univerzita, Brno.
KONEČNÝ, L. 1984-1985: Znojmo, kaple Nanebevzetí P. Marie a sv. Kateřiny.Výzkum románské architektury na Moravě IV. Sborník prací Filozofické fakulty Masarykovy univerzity F, 18-29, 29-41.

KONECNÝ, L. J. 2005: Románská rotunda ve Znojmě, Ikonologie maleb a architektury. Host, Brno.

KOVÁRNÍK, J. 2007: Nový poznatek ke stavební technologii románské rotundy sv. Kateřiny ve Znojmě. Ve službách archeologie 1/07, 162172.

KRZEMIENSKA, B., MERHAUTOVÁ, A., TŘEŠTÍK, D. 2000: Moravšti Přemyslovci ve znojemské rotundě. Set out, Praha.

KUČKOVÁ, Š., HYNEK, R., KODÍČEK, M. 2007: Identifikace proteinových komponent v omítkách rotundy sv. Kateřiny ve Znojmě. Ve službách archeologie 1/07, 173-176.

MENCL, V. 1959: Architektura předrománských Čech. Umění 7, 349.

MERHAUTOVÁ, A., TŘEŠTÍK, D. 1984: Románské umění v Čechách a na Moravě. Odeon, Praha.

MĚŘÍNSKÝ, Z. 1999: Několik poznámek k výzkumům znojemské rotundy a hradu. Časopis matice moravské 118, 453-463.

REIDINGER, E. 2005: Mittelalterliche Kirchenplanung in Stadt und Land aus der Sicht der bautechnischen Archäologie, Lage, Orientierung und Achsknick. Beiträge zur Mittelalterarchäologie in Österreich 21, 49-66.

RICHTER, V., SAMEK, B., STEHLÍK, M. 1966: Znojmo. Odeon, Praha. SPUNAR, P. 1995: Kultura středověku. Academia: Praha.

VLČEK, M. 1997: Znojemská rotunda z pohledu stavebního inženýra. In: Ciprian, P.(Eds): Znojemská rotunda ve světle vědeckého poznání, vědecká konference, 23.-25. 9. 1996. Jihomoravské muzeum ve Znojmě, Znojmo, 161-165.

VŠETEČKOVÁ, Z. 2003: Nástěnné malby ve znojemské rotundě. Několik poznámek k jejich interpretaci. In: Kratochvílová, M. (Ed.): Znojemská rotunda, Malby $v$ národní kulturní památce Rotunda sv. Kateřiny a výsledky současného výzkumu, Sborník z 2. konference o rotundě, konané 25.-26. června 2003. Město Znojmo, Znojmo,124-130.

WIHODA, M. 1997: Znojemští údělníci v politickém a mocenském systému přemyslovské monarchie. In: Ciprian, P. (Ed.): Znojemská rotunda ve světle vědeckého poznání, vědecká konference, 23.-25. 9. 1996. Jihomoravské muzeum ve Znojmě, Znojmo, 18-45.

WIHODA, M. 1999: Conradus secundus fundator aneb úvahy nad významem jedné čárky. Časopis matice moravské 118, 437-443.

WIHODA, M. 2006: Testament knížete Břetislava. In: Sága moravských premyslovců, Život na Moravě od XI do počátku XIV století. Vlastivědné muzeum v Olomouci, Muzeum města Brna, Olomouc, Brno, 33-50.

ZEMAN, A., RŮŽIČKOVÁ, E. 1997: Výzkum látkového složení malt ze znojemské rotundy sv. Kateřiny. In: Ciprian, P.(Ed.): Znojemská rotunda ve světle vědeckého poznání, vědecká konference, 23.-25. 9. 1996. Jihomoravské muzeum ve Znojmě, Znojmo,133-138. 